\title{
Assessment of plant growth promoting activities and abiotic stress tolerance of Azotobacter chroococcum strains for a potential use in sustainable agriculture
}

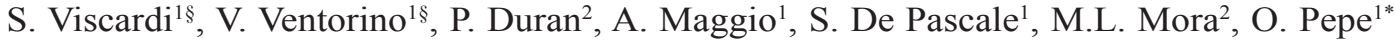 \\ $\S$ These authors contributed equally to this paper
}

\begin{abstract}
${ }^{1}$ Department of Agricultural Sciences, University of Naples Federico II, Via Università 100, 80055 Portici (Naples), Italy. *Corresponding author: olipepe@unina.it ${ }^{2}$ Center of Plant, Soil Interaction and Natural Resources Biotechnology, Scientific and Technological Bioresource Nucleus, Universidad de La Frontera, Avenida Francisco Salazar, 01145 Temuco, Arancanía, Chile.
\end{abstract}

\begin{abstract}
This study aimed to select and characterize bacterial strains with multiple plant growth promotion properties able to tolerate drought and salinity stress in order to improve plant growth performance under abiotic stresses. Plant growth promoting activities were evaluated in 106 bacterial strains isolated by soil, compost, lignocellulosic biomasses and food matrices. Two strains A. chroococcum $67 \mathrm{~B}$ and $76 \mathrm{~A}$ were selected for their multiple plant growth promotion activities $\left(\mathrm{N}_{2}\right.$-fixing activity, synthesis of siderophores and indole-3-acetic acid) as well as antimicrobial activity against Sclerotinia minor. Moreover, the selected strains were tested for their tolerance to drought and salinity stress in in vitro experiments evaluating their growth, production of SOD, CAT, proline and ACC deaminase. The two Azotobacter chroococcum strains exhibited high tolerance to salt and drought stresses and could alleviate the negative effects exerted by abiotic stress on tomato plants. Overall results showed that the strains Azotobacter chroococcum 67B and Azotobacter chroococcum 76A could be interesting candidates to be employed as bio-effector in sustainable agricultural systems also under stressful conditions leading to improved economic and environmental benefits.
\end{abstract}

Keywords: Azotobacter chroococcum, bioeffectors, abiotic stress, antioxidant enzymes, rhizo-competence 


\section{Introduction}

Abiotic stresses, such as drought and salinity, are among the major environmental constraints that limit growth, productivity and quality of crops (Yang et al., 2009). The United Nations Food and Agriculture Organization estimated that approximately $20 \%$ irrigated lands are affected by increasing salinity (Rozema and Flowers, 2008). In Europe, twenty-six countries have reported cases of salinization with higher frequency in Mediterranean coastal areas (Flowers, 2004). Salinity and drought primarily cause disruption of ionic and water homeostasis of plant cells with consequent deleterious effects on general growth and eventually plant death (Maggio et al., 2007). Therefore, identifying and developing eco-friendly strategies that can ameliorate plant growth in response to abiotic stresses are an immediate need in agricultural systems that have to cope with the jeopardies of climate change increasingly. Microorganisms or active natural compounds (bioeffectors) provided to the plant root-zone may directly or indirectly affect plant performance under both favorable and unfavorable environments. Bioeffectors (BE) include plant growth-promoting rhizobacteria (PGPR) that have been proven to improve plant performance based on biological functions occurring at the soil-plant-microbe interfaces. The use of PGPR as elicitors of mechanisms facilitating plant tolerance to abiotic stresses has emerged as a promising strategy to improve plant adaptation and resource use efficiency in hostile environments (Yang et al., 2009). The PGPR can benefit plant development through multiple mechanisms of action. They can operate directly through the production of substances which promote growth and increase nutrient availability in soil and their uptake, or indirectly through the suppression of plant pathogens (Ribeiro and Cardoso, 2012). Nitrogen-fixing bacterial strains, including several belonging to the genus Azotobacter, have been used successfully in agriculture applications (Islam et al., 2013). These strains have been characterized well for their excellent nitrogen fixing properties as well as for their siderophores, indol-3-acetic acid and exopolysaccharides (EPS) production, which may benefit plant growth/nutrient availability and soil water retention properties (Gauri et al., 2012). However, multiple facets of the mechanisms of action of PGPR may include additional properties beyond their characterized function of biofertilizers and/or biological control agents. All these proprieties could enhance the tolerance to abiotic stress in inoculated plants (Ruzzi and Aroca, 2015). On these bases, we aimed at selecting and characterizing bacterial BE with multiple plant growth promotion properties and antimicrobial activity. The selected PGPB strains were also tested for their ability to tolerate drought and salinity stress and improve plant growth performance.

\section{Materials and Methods}

\subsection{Microbial strains tested and evaluation of plant growth promoting traits}

One hundred six strains, previously isolated from soil (22 strains), compost (10 strain), lignocellulosic biomasses (41 strains) and food matrices (33 strains) (Anastasio et al., 2010; Pepe et al., 2013a; Ventorino et al., 2015), were tested for their putative plant growth promotion activities. Based on their origins, bacterial strains were streaked on PCA (Oxoid, Milan, Italy), MRS (Oxoid, Milan, Italy) and the nitrogenfree medium LG Agar (Pepe et al., 2013a). Plates were examined after $48 \mathrm{~h}$ (PCA and MRS), or 3 and 7 days (LG agar) of incubation at $28^{\circ} \mathrm{C}$, and the pure colonies were used for assaying their ability to produce indole-3-acetic acid (IAA) and siderophores, 
solubilize phosphate and exert antimicrobial activity against soil-borne pathogens. Microorganisms' ability to produce siderophores was assessed by Chrome Azurol S (CAS) agar essay (Silva-Stenico et al., 2005). The ability to solubilize phosphates was assayed by inoculating the strains on Pikovskaya's agar (Anastasio et al., 2010; Ventorino et al., 2014).

Screening of the strains was carried out by the in situ qualitative assay described by Bric et al. (1991) for the production of indol-3-eacetic acid (IAA). Based on a distinctive red halo around the colonies is positive indication for the production of IAA. Moreover, the production of IAA was quantified only for selected strains using the Salkowski colorimetric assay as previously described (Ventorino et al., 2014).

Antimicrobial antagonism was evaluated using the dual culture method described by Hammami et al. (2013) against Sclerotinia minor CBS 112.17, Fusarium oxysporum f.sp. lycopersici CBS 308.91, Fusarium oxysporum f.sp. melonis CBS 423.90, Fusarium solani CBS 188.34. Phytopathogens were cultivated in malt extract agar (Oxoid, Milan, Italy) at $28{ }^{\circ} \mathrm{C}$. Conidia were harvested from the surface of plates by flooding the 10-day-old cultures with $9 \mathrm{ml}$ of sterilized distilled water and gently scraping with a sterilized glass rod.

The conidial concentration was determined with a Thoma counting chamber (Hawksley UK). An agar over-layer (agar $0.7 \%$ ) containing a concentration of $10^{5}$ conidia $\mathrm{ml}^{-1}$ of each fungal pathogen was placed into PCA medium and then, the bacterial strains were picked on the plate surface. After incubation for $48 \mathrm{~h}$ at $28^{\circ} \mathrm{C}$, the antimicrobial activity of tested bacterial strains was highlighted by the presence of a halo around the bacterial colony without fungal growth.

\subsection{Phenotypic and genotypic characterization of se- lected strains}

The Azotobacter chroococcum strain 67B identified by biochemical and molecular methods (Pepe et al., 2013a), and strain 76A were selected according to PGP activities. The strain 76A was identified based on of microscopical features (phase-contrast microscopy, shape, dimension and presence of spore), biochemical characteristics (Gram-stains, catalase activity) and by $16 \mathrm{~S}$ rRNA gene sequencing using the synthetic oligonucleotide primers fD1 (5'-AGAGTTTGATCCTGGCTCAG-3') and rD1 (5'-AAGGAGGTGATCCAGCC-3'). PCR mixture and conditions were performed as described by Ventorino et al. (2015). The presence of the PCR products was verified by agarose $(1.5 \% \mathrm{wt} / \mathrm{vol})$ gel electrophoresis at $100 \mathrm{~V}$ for $1 \mathrm{~h}$ and the products were purified using a QIA quick gel extraction kit (Qiagen S.p.A, Milan, Italy) and sequenced. The DNA sequences were determined and analyzed, as previously reported (Pepe et al., 2013b) and finally compared with the GenBank nucleotide data library using the Blast software (Reference RNA sequences database) at the National Centre of Biotechnology Information website (http://www.ncbi. nlm.nih.gov/Blast.cgi).

The obtained 16S rRNA gene sequence was deposited in the GenBank nucleotide database under the accession number KX108861.

\section{3. $\mathrm{NaCl}$ tolerance of selected strains}

The two selected bacterial strains were tested for their salt tolerance in liquid cultures as previously described (Ventorino et al., 2012). Briefly, $10 \mathrm{ml}$ yeast mannitol (YM) medium supplemented with $\mathrm{NaCl}$ at $1 \%, 3 \%$ and $5 \%(\mathrm{w} / \mathrm{v})$ concentrations were inoculated with each bacterial strain. The standard YM medium 
with $0.1 \%(\mathrm{w} / \mathrm{v}) \mathrm{NaCl}$ was used as control. Samples were withdrawn periodically at an interval of $4 \mathrm{~h}(0$, $4,8,12,16,20,24,28,32,36,40,44$ and $48 \mathrm{~h}$ ) and cell growth was determined measuring optical density OD600 by using a spectrophotometer (Eppendorf, Milan, Italy). All tests were conducted in triplicates.

\subsection{Production of the antioxidant enzymes}

Superoxide dismutase (SOD) and catalase (CAT) activities were assayed as described by Duran et al. (2015). Briefly, bacterial strains were inoculated in YM medium supplemented with $\mathrm{NaCl}$ at $0 \%, 5 \%, 7.5 \%$ and $10 \%(\mathrm{w} / \mathrm{v})$ concentrations. After incubation at $28^{\circ} \mathrm{C}$ for $96 \mathrm{~h}$, enzymatic extracts were obtained as described by Lin et al. (2009). Total protein concentration was determined by the Coomassie blue G-250 dye-binding assay using bovine serum albumin as a standard. The SOD activity was assessed according to its capacity to inhibit photochemical reduction of nitroblue tetrazolium NBT (Armada et al., 2016). One enzyme unit was defined as the amount of free extract that inhibited about $50 \%$ the reduction of nitroblue tetrazolium at $\mathrm{pH} 7.0$ (Duran et al., 2016). The total specific enzyme activity was expressed as U mg protein-1 (Bojadzhieva and Emanuilova, 2005). Catalase activity was assayed with $15 \mathrm{ml}$ enzymatic extract, $29 \mathrm{ml} 0.1 \mathrm{M} \mathrm{KPO}_{4}(\mathrm{pH} 7.0$ ), $188 \mathrm{ml}$ ultrapure distilled water and $58 \mathrm{ml} \mathrm{H}_{2} \mathrm{O}_{2}(30 \%)$, which were added into the automatic injector Synergy TM HT multimode microplate reader. The optical density of the solution was recorded after $60 \mathrm{~s}$ at $240 \mathrm{~nm}$. All enzymatic activities were calculated according to the equation derived by Whiteley and Lee (2006):

$$
\text { Activity }=\Delta \mathrm{A}(\mathrm{V} / \mathrm{etv})
$$

Where, $\Delta \mathrm{A}$ is the change in absorbance, $V$ is the total volume in the assay mixture, $\varepsilon$ is the extinction coeficient in $\mathrm{mL} \mu \mathrm{mol}^{-1}, \mathrm{t}$ is the time expressed in min and vis the volume of the sample.

\subsection{Proline production by selected strains under in- creasing $\mathrm{NaCl}$ concentrations}

Bacterial strains were inoculated into YM medium with $0.1 \%, 5 \%, 7.5 \%$ and $10 \%(\mathrm{w} / \mathrm{v})$ of $\mathrm{NaCl}$. After incubation at $28{ }^{\circ} \mathrm{C}$ for $96 \mathrm{~h}$, samples were centrifuged at 10,000 rpm for $10 \mathrm{~min}$. Pellets were washed twice with $0.85 \% \mathrm{NaCl}$ solution and suspended in $1.5 \mathrm{ml}$ of lyses buffer $(100 \mathrm{mM}$ EDTA, $50 \mathrm{mM} \mathrm{NaCl}, \mathrm{pH} 6.9)$ and $1 \mathrm{mg} \mathrm{ml}^{-1}$ lysozyme (Sigma). Then, samples were incubated at $30{ }^{\circ} \mathrm{C}$ for $90 \mathrm{~min}$ and centrifuged at 3,000 rpm for $10 \mathrm{~min}$. Finally, supernatants were centrifuged at 13,000 rpm for $25 \mathrm{~min}$ (Duran et al., 2015) and proline accumulation was determined by a colorimetric method based on proline reaction with ninhydrin as described by Bates et al.(1973).

\subsection{Quantification of ACC deaminase activity of se- lected strains}

The evaluation of 1-amino- cyclopropane-1- carboxylate deaminase (ACCd) activity was performed according to Penrose and Glick (2003). In details, bacterial strains were inoculated in to $5 \mathrm{ml} \mathrm{DF}$ salt medium containing $\left(\mathrm{NH}_{4}\right)_{2} \mathrm{SO}_{4}$ as nitrogen source (Penrose and Glick 2003). After incubation at 28 ${ }^{\circ} \mathrm{C}$ for 48 hunder shaking (175 rpm), $0.1 \mathrm{ml}$ aliquots from each culture were removed, washed, transferred to test tubes with $5 \mathrm{ml} \mathrm{DF}$ salt medium containing $3 \mathrm{mM} \mathrm{ACC} \mathrm{(Calbiochem} 1$ ) as a sole nitrogen source, and incubated at $28{ }^{\circ} \mathrm{C}$ for $48 \mathrm{~h}$ under shaking. ACC deaminase activity was determined measuring the amount of $\alpha$-ketobuty rate produced after the hydrolysis of ACC. The amount of $\alpha$-ketobuty rate was quantified by spectroscopic absorbance measurements at $540 \mathrm{~nm}$ according to the standard curve ranging from 0.1 to $1 \mu \mathrm{M}$. 


\subsection{In vitro drought and salt stress tolerance of Azo- tobacter-treated tomato seedlings}

The Azotobacter chroococcum 67B and A. chroococcum 76A strains were grown in a $200 \mathrm{ml}$ YM medium at $28{ }^{\circ} \mathrm{C}$ for $24 \mathrm{~h}$ in a rotary shaker at $150 \mathrm{rpm}$. Strain cultures were harvested at the late exponential phase of growth and suspended in quarter-strength Ringer's solution (Oxoid) until achieving microbial counts of approximately $1 \times 10^{9} \mathrm{CFU} \mathrm{ml}^{-1}$ (Thoma counting chamber, Hawksley UK). Tomato (Lycopersicon esculentum cv. Micro-Tom) seeds were surface sterilized by $10 \mathrm{~min}$ immersion in $70 \%$ ethanol followed by 10 minimmersion in $2.5 \%(\mathrm{v} / \mathrm{v})$ sodium hypochlorite with $0.05 \%$ Tween-20 and then washed in sterile distilled water. Seeds were sown in magenta boxes containing $82 \mathrm{~g}$ sterile quartz sand and watered with nitrogen free nutrient solution (Priefer, 2001) inoculated with bacterial strains (alone or in combination) to reach a microbial concentration of approximately $1 \times 10^{6}$ cells g$^{-1}$. Plants were grown under controlled conditions with a constant temperature of $23 \pm 1{ }^{\circ} \mathrm{C}$ and a $16 \mathrm{~h}_{\text {day }}{ }^{-1}$ photoperiod, and watered with nitrogen free nutrient solution for 8 weeks. Non-inoculated plants were used as control. Bacterial concentrations were monitored collecting quartz sand samples immediately after sowing and every 7 days during the 8 weeks of the experiment. Briefly ten days after seeds germination, the magenta boxes were kept without cap and without watering with nitrogen-free nutrient solution, until complete dehydration of quartz sand. Seedlings were rewatered with $15 \mathrm{ml}$ of nitrogen-free nutrient solution after $72 \mathrm{~h}$, and the ability of bacterial strains to alleviate drought stress in the seedlings was evaluated comparing the aspect of no-inoculated and inoculated plants.

An additional in vitro test was also carried out in order to evaluate the growth rate of selected microbial strains used for inoculating tomato plants cultivated under salt stress conditions for two months.
Inocula preparation and application and seed sterilization were performed as reported above. Tomato plants were sown in magenta box containing sterile quartz sand and inoculated with A. chroococcum 67B and A. chroococcum 76A. Non-inoculated plants were used as control. Salinity treatments consisted of three $\mathrm{NaCl}$ concentrations ( $\mathrm{w} / \mathrm{v})$ in the irrigation water $(0 \%, 0.5 \%$ and $1 \%)$. All tests were performed in triplicate.

\subsection{Study of rhizo-competence by exploiting Fluo-} rescent $\mathrm{Al}^{3+}$-complex produced by Azotobacter chroococcum 67B and Azotobacter chroococcum $76 \mathrm{~A}$

The strains A. chroococcum 67B and A. chroococcum 76A were inoculated separately into a growth medium containing $2 \mathrm{mM}$ of $\mathrm{Al}^{3+}, 4.84 \mathrm{~g} \mathrm{l}^{-1}$ of succinic acid, $1.01 \mathrm{~g} \mathrm{l}^{-1}$ of $\mathrm{NH}_{4} \mathrm{Cl}, 50 \mathrm{ml}$ glycerol, $1 \mathrm{~g} \mathrm{l}^{-1}$ of $\mathrm{KCl}, 0.02 \mathrm{~g} \mathrm{l}^{-1}$ of $\mathrm{CaCl}_{2}, 0.86 \mathrm{~g} \mathrm{l}^{-1}$ of $\mathrm{K}_{2} \mathrm{SO}_{4}, 0.01$ $\mathrm{g} \mathrm{l}^{-1}$ of $\mathrm{KH}_{2} \mathrm{PO}_{4}, 0.04 \mathrm{~g} \mathrm{l}^{-1}$ of $\mathrm{K}_{2} \mathrm{HPO}_{4}, 0.002 \mathrm{~g} \mathrm{l}^{-1}$ of $\mathrm{MgCl}_{2}, 0.02 \mathrm{~g} \mathrm{l}^{-1}$ of $\mathrm{K}_{2} \mathrm{SO}_{4}$. After incubation at $28^{\circ} \mathrm{C}$ for $48 \mathrm{~h}$, the formation of complex $\mathrm{Al}^{3+}$-siderophore was observed by confocal laser scanning microscope (Olympus Fluoview 1000). Inoculated media without $\mathrm{Al}^{3+}$ as well as non-inoculated medium were used as controls.

An in vitro assay under sterile conditions was carried out to evaluate the colonization of root of tomato plants. In details, $100 \mu \mathrm{l}$ of bacterial culture with a concentration of $1 \times 10^{9} \mathrm{UFC} \mathrm{ml}^{-1}$ were inoculated into pots containing seven day tomato plants with the growth liquid medium described above. The $\mathrm{Al}^{3+}$-complex was observed using a confocal laser scanning microscope (Olympus Fluoview 1000) and Al content was estimated by Energy dispersive XRay Spectrometer Detector (EDX, Hitachi, Japan). Non-inoculated plants were used as control. All experiments were performed in triplicates. 


\subsection{Statistical analyses}

Data sets were analyzed by one-way ANOVA followed by Tukey's HSD post hoc for pairwise comparison of means (at $\mathrm{P}<0.05$ ) using SPSS 19.0 statistical software package (SPSS Inc., Cary, NC, USA).3.

\section{Results}

\subsection{Characterization of plant growth promotion ac-} tivities

A total of 106 bacteria were tested for their potential plant growth promoting activities including ability to produce indole-3-acetic acid (IAA) and siderophores, solubilize phosphate, and exert antimicrobial activity against soil-borne pathogens. The results indicated that $20.0 \%$ of strains were able to produce siderophores, $31.8 \%$ solubilized phosphate, $35.3 \%$ synthetized IAA and $12.9 \%$ showed antimicrobial activity against different tested phytopathogens (data not shown).

Upon detailed analysis of these properties, bacterial strains A. chroococcum 76A and 67B (Pepe et al ., 2013a) were selected for their multiple plant growth promotion activities. Strain 76A was identified using a polyphasic approach based on their phenotypical (opaque, convex, mucoid and smooth colonies developing a brown-black pigment aging, single Gram-negative rod-shaped cells) and molecular (16S rRNA gene sequence - 99\% identity with Azotobacter chroococcum specie using BLAST software) characteristics.

The A. chroococcum 67B, chosen according to its high $\mathrm{N}_{2}$-fixing activity (Pepe et al., 2013a), was able to synthetize siderophores (halo dimension 7.0 \pm 0.04 $\mathrm{mm})$ and relatively high amount of IAA (28.0 \pm 1.29 $\mathrm{mg} \mathrm{1^{-1 }}$ ) as well as it showed ACC deaminase activity producing $0.96 \mu \mathrm{M}$ of $\alpha$-ketobutyrate protein $\mathrm{mg}^{-1}$ in 15 min (Table 1). Interestingly, A. chroococcum 76A showed the highest orange halo around the colony in CAS agar $(14 \pm 0.07 \mathrm{~mm})$ corresponding to the highest relative siderophores production as well as the highest IAA production ( $\left.34.0 \pm 0.39 \mathrm{mg} \mathrm{l}^{-1}\right)$. Moreover, $A$. chroococcum 76A presented ACC deaminase activity ( $0.96 \mu \mathrm{M}$ of $\alpha$-ketobutyrate protein $\mathrm{mg}^{-1}$ in $15 \mathrm{~min}$ ). In addition, both selected free-living $\left(\mathrm{N}_{2}\right)$-fixing bacterial strains exerted antimicrobial activity against Sclerotinia minor CB.,S 112.17 (Table 1).

Table 1. Plant growth-promoting and antimicrobial activities of Azotobacter chroococcum 67B and Azotobacter chroococcum 76A.

\begin{tabular}{|c|c|c|c|c|c|c|}
\hline Strain & $\begin{array}{c}\text { Siderophores } \\
\text { production }^{*}(\mathrm{~mm})\end{array}$ & $\begin{array}{c}\text { ACC deaminase } \\
\text { activity }^{\dagger}\end{array}$ & $\begin{array}{c}\text { IAA production } \\
\left(\mathrm{mg} \mathrm{l}^{-1}\right)\end{array}$ & $\begin{array}{c}\text { Antimicrobial } \\
\text { activity }^{\ddagger}\end{array}$ & $\begin{array}{l}\text { The closest phylogenetic } \\
\text { relatives (identity percentage) }\end{array}$ & Accession number \\
\hline $67 \mathrm{~B}$ & $7.0 \pm 0.04$ & 0.96 & $28.0 \pm 1.29$ & $\begin{array}{c}\text { + against Sclerotinia } \\
\text { minor CBS } 112.17\end{array}$ & Azotobacter chroococcum (99\%) & $\begin{array}{c}\text { JX050260 (Pepe et al., } \\
\text { 2013a) }\end{array}$ \\
\hline $76 \mathrm{~A}$ & $14.0 \pm 0.07$ & 0.96 & $34.0 \pm 0.39$ & $\begin{array}{c}\text { + against Sclerotinia } \\
\text { minor CBS } 112.17\end{array}$ & Azotobacter chroococcum (99\%) & KX108861 (this study) \\
\hline
\end{tabular}

${ }^{*}$ Halo size $(\mathrm{mm})=$ diameter of clearing or halo zone/colony diameter, values represent the means $\pm \mathrm{SD}$ of three replicates; $\uparrow \mu \mathrm{M}$ $\alpha$-ketobutyrate mg protein ${ }^{-1}$ in $15 \mathrm{~min} ;{ }^{\star}+$ positive. 


\subsection{Salt tolerance}

The two diazotrophic strains $A$. chroococcum 67B and $76 \mathrm{~A}$ were found to be salt-tolerant since they were able to grow in the liquid culture medium at increasing sodium chloride concentrations (Figure 1). The A. chroococcum 67B, performed slightly better than 76 A because it reached an O.D. ${ }_{600 \mathrm{~nm}}$ around 1, in the interval from 24 to 36 hours of incubation at $28^{\circ} \mathrm{C}$ at every $\mathrm{NaCl}$ concentration tested (from 0.0 to $5.0 \%$; $\mathrm{w} / \mathrm{v})$ (Figure 1A). This trend was maintained until the end of the experiment ( $48 \mathrm{~h}$ ).

For A. chroococcum $76 \mathrm{~A}$, growth was slower, reachinga maximum O.D. ${ }_{600 \mathrm{~nm}}$ of 0.8 from 24 to 36 hours depending on salt concentration (Figure 1B). Subsequently (up to $48 \mathrm{~h}$ ) the microbial concentration for this strain gradually decreased at all $\mathrm{NaCl}$ concentrations (from 0.0 to $5.0 \%$ ).
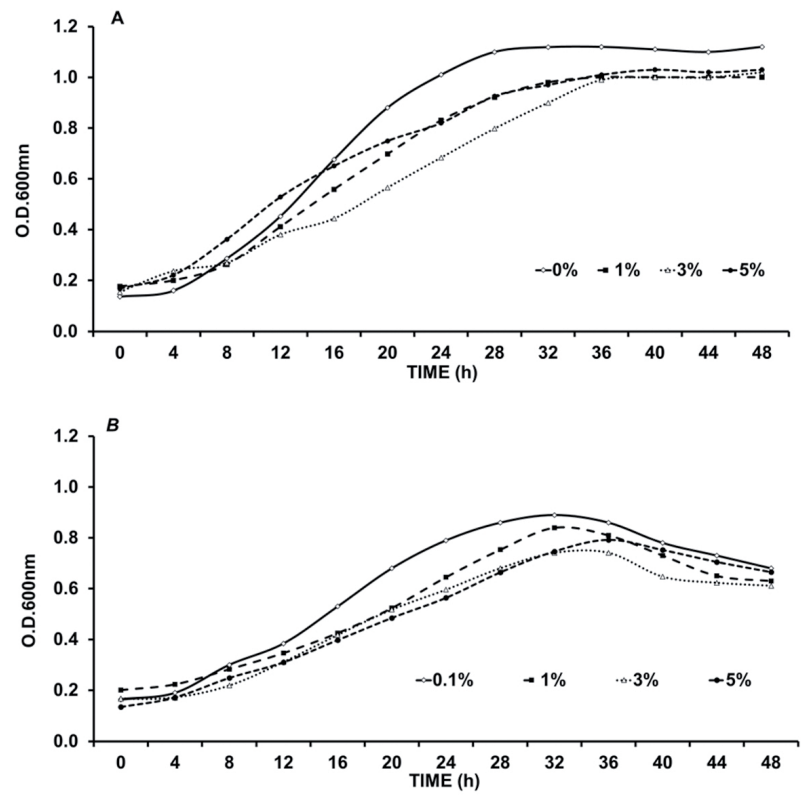

Figure 1. Microbial growth curves of strains Azotobacter chroococcum 67B (A) and Azotobacter chroococcum $76 \mathrm{~A}$ (B) in liquid medium (YMB) supplemented with different $\mathrm{NaCl}$ concentrations $(0.1,1 \%, 3 \%$ and $5 \%)$ incubated at $28^{\circ} \mathrm{C}$ for $48 \mathrm{~h}$.

\subsection{Antioxidant activities and proline production}

Salt stress significantly increased SOD activity in the two free-living nitrogen fixers $A$. chroococcum 67B and A. chroococcum 76A (Figure 2A). A positive correlation between $\mathrm{NaCl}$ concentration and SOD activity was found in the strain A. chroococcum 67B. In particular, a constant increase of SOD was observed when increasing $\mathrm{NaCl}$ concentration reaching a value of $12163.5 \mathrm{U} \mathrm{g}^{-1}$ protein in the liquid medium containing $10 \%$ of $\mathrm{NaCl}$ (Figure 2A). For A. chroococcum $76 \mathrm{~A}$ the highest SOD activity was recorded at $5 \%$ of $\mathrm{NaCl}$, although it did not differ significantly from $0 \%$ control (Figure 2A).

Moreover, salt stress did not exert any effect on CAT activity in the two strains (Figure 2B). 

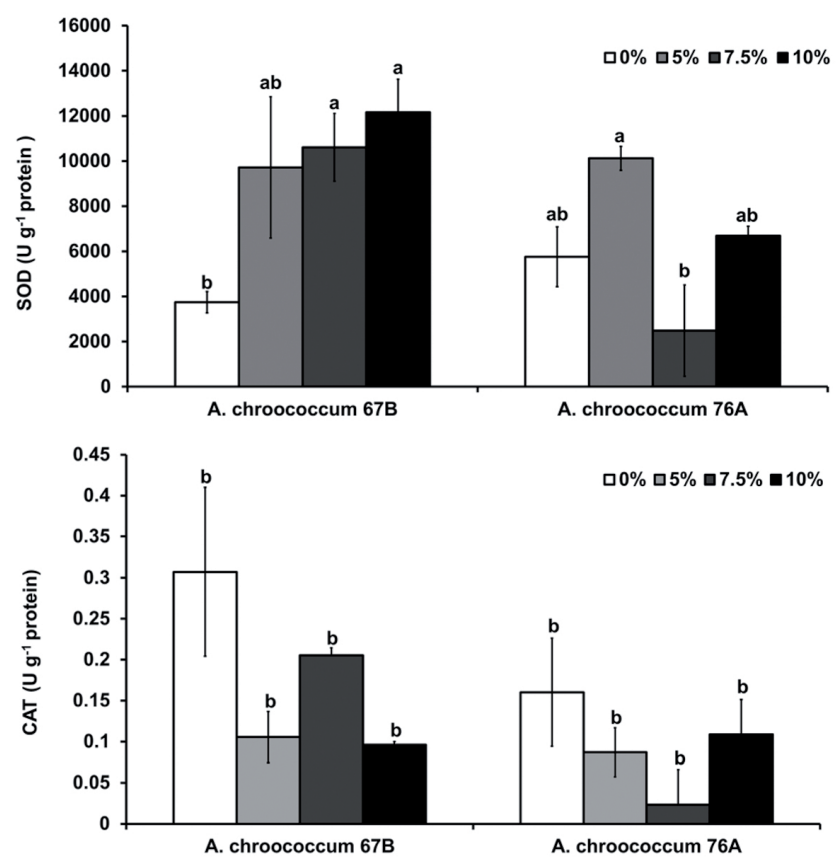

Figure 2. Superoxide dismutase (SOD) activity (A) and Catalase (CAT) activity (B) of strains Azotobacter chroococcum 67B and Azotobacter chroococcum 76A in liquid media supplemented with different $\mathrm{NaCl}$ concentrations. Different letters indicate significant differences $(\mathrm{P}<0.05)$ between $\mathrm{NaCl}$ treatments in each strain.

Finally, A. chroococcum 67B produced $0.07 \mathrm{ng} \mathrm{ml}^{-1}$ proline after $96 \mathrm{~h}$ incubation in liquid media with different $\mathrm{NaCl}$ concentrations with no significant difference among all tested conditions (Table 2).
In contrast, high levels of $\mathrm{NaCl}(7.5 \%$ and $10 \%)$ induced a significant increase of proline production (up to $0.09 \mathrm{ng} \mathrm{ml}^{-1}$ ) in strain A. chroococcum $76 \mathrm{~A}$ (Table 2).

Table 2. Proline accumulation ( $\mathrm{ng} \mathrm{ml}^{-1}$ ) by Azotobacter chroococcum 67B and Azotobacter chroococcum 76A in YM media supplemented with different $\mathrm{NaCl}$ concentrations.

\begin{tabular}{ccc}
\hline$\% \mathrm{NaCl}$ & Azotobacter chroococcum 67B & Azotobacter chroococcum $76 \mathrm{~A}$ \\
\hline 0.01 & $0.07 \pm 0.00^{\mathrm{b}}$ & $0.07 \pm 0.00^{\mathrm{b}}$ \\
5.00 & $0.07 \pm 0.00^{\mathrm{b}}$ & $0.07 \pm 0.00^{\mathrm{b}}$ \\
7.50 & $0.07 \pm 0.00^{\mathrm{b}}$ & $0.09 \pm 0.01^{\mathrm{a}}$ \\
10.0 & $0.07 \pm 0.00^{\mathrm{b}}$ & $0.09 \pm 0.01^{\mathrm{a}}$ \\
\hline
\end{tabular}

Values with different letters indicate significant differences $(\mathrm{P}<0.05)$. 


\subsection{In vitro microbial and plant stress tolerance}

The A. chroococcum 67B and 76A strains were tolerant to drought and salt stresses as showed by in vitro growth tests. The two A. chroococcum strains, inoculated alone and together at a concentration of about
6 Log CFU $\mathrm{g}^{-1}$ in the sterilized quartz sand, were able to grow under water shortage and saline stress conditions. Specifically, the diazotrophic strains significantly increased after 7 days of incubation under drought condition $(\mathrm{P}<0.5)$ reaching a plateau at $9 \mathrm{Log}$ CFU g-1 quartz sand after 28 days (Figure $3 \mathrm{~A}$ ).
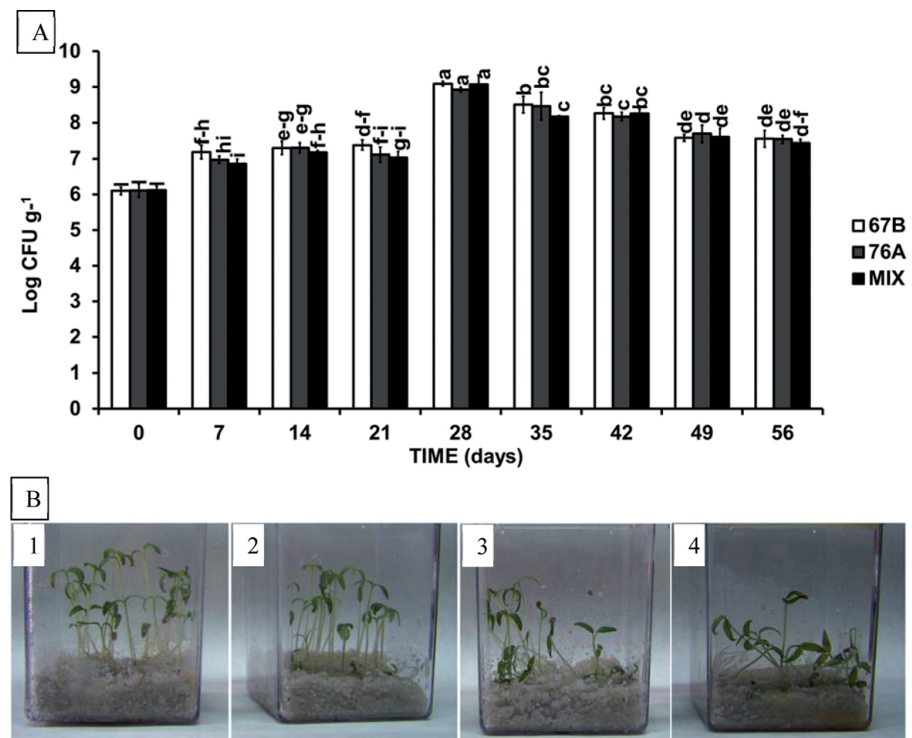

Figure 3. (A) Microbial growth of diazotrophic strains inoculated in quartz sand in the presence of tomato plants exposed to drought stress. 67B, Azotobacter chroococcum 67B; 76A, Azotobacter chroococcum 76A; MIX, inoculated with A. chroococcum 67B and A. chroococcum 76A. Different letters indicate significant differences ( $\mathrm{P}<0.05)$.(B) Representative image of Lycopersicon esculentum plants inoculated with A. chroococcum 67B (1), A. chroococcum 76A (2), mix of A. chroococcum 67B and A. chroococcum 76A (3) and non-inoculated plants (4) after drought stress imposed as described in material and methods section.

Then, their concentration progressively decreased to approximately 7.5 $\mathrm{Log}_{\mathrm{CFU} \mathrm{g}}{ }^{-1}$ quartz sand $(\mathrm{P}<0.5)$ until the end of incubation (day 56).Interestingly, a positive effect of the inoculum on Lycopersicon esculentum cv. Micro-Tom plants was detected as visual gaining of turgidity observed in magenta boxes inoculated with A. chroococcum strains, after an addition of the nitrogen-free nutrient solution (Figure 3B).
Moreover, salt stress did not exert negative effects on microbial growth of both strains since they were able to grow at different $\mathrm{NaCl}$ concentrations $(0,0.5$ and 1.0 $\%$ ) remaining viable until the end of the experiment and overall confirming the results obtained in liquid growth medium. After 30 days of incubation at $23^{\circ} \mathrm{C}$, the two strains showed a significant increase of approximately 1 Log CFU g-1 at everytested salt concentrations (Figure 4). 
Specifically, strain A. chroococcum 76A grew up to $8.78 \pm 0.13$ Log CFU g ${ }^{-1}$ quartz sand at day 30 , after which time its viability varied depending on the $\mathrm{NaCl}$ concentration of the growth medium. While the bacterial growth was quite steady at 0.0 and 1.0 $\%$ of $\mathrm{NaCl}$ on day 60 , the bacterial concentration significantly decreased down to $7.93 \pm 0.13 \mathrm{Log}_{\mathrm{CFU} \mathrm{g}}{ }^{-1}$ quartz sand at $0.5 \% \mathrm{NaCl}$ (Figure 4).

In contrast, strain A. chroococcum 67B showed a significant constant decrease at all salt concentrations from day 30 to 60 (Figure 4). Interestingly, during this time, the decrease of $A$. chroococcum 67B was more evident than $A$. chroococcum $76 \mathrm{~A}$ at increasing $\mathrm{NaCl}$ concentration, highlighting a negative correlation between this strain and salt concentration.

Overall, the concentration of the two strains was still high in the presence of high $\mathrm{NaCl}$ concentrations, which would be highly damaging and/or lethal to plants (about 7.2-7.5 Log CFU g-1 quartz sand), at the end of incubation period (day 60) (Figure 4). Preliminary results with salt stressed tomato plants, pre-treated with A. chroococcum 76A inoculum in the root-zone, confirmed the beneficial properties of this treatment to plant growth in saline environment (data not shown).

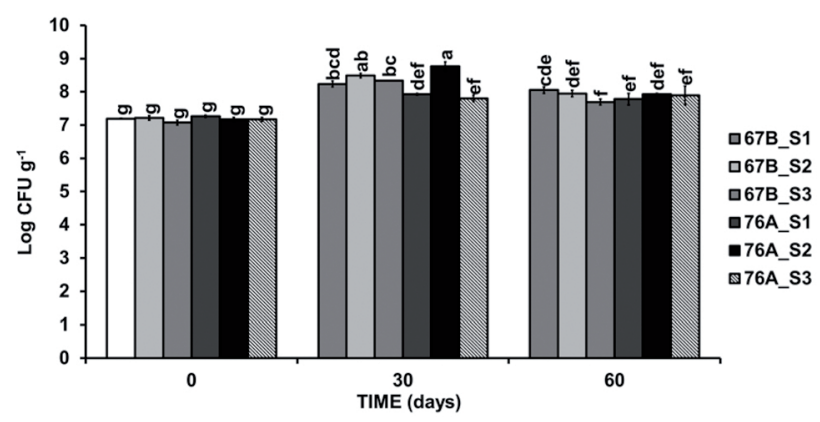

Figure 4. Microbial growth of diazotrophic strains inoculated into quartz sand in proximity of salt stressed tomato plants. 67B, Azotobacter chroococcum 67B; 76A, Azotobacter chroococcum 76A; S1, 0\% NaCl; S2, 0.5\% NaCl; $\mathrm{S} 3,1 \% \mathrm{NaCl}$. Different letters indicate significant differences $(\mathrm{P}<0.05)$.

\subsection{Study of rhizo-competence by exploiting Fluores-} cent $A l^{3+}$-complex produced by Azotobacter chroococcum $67 \mathrm{~B}$ and Azotobacter chroococcum $76 \mathrm{~A}$

Siderophores produced by Azotobacter chroococcum 67B and Azotobacter chroococcum 76A were able to form complexes with $\mathrm{Al}^{+3}$ as shown by the fluorescence emission assessed by confocal microscope (Figure 5A, 5B). Fluorescence was compared with non-inoculated medium and inoculated medium without $\mathrm{Al}$ (Figure 5C, 5D) demonstrating that complexes formation was due to Al chelation. Moreover, fluorescence emission by the Al-siderophore complexes detected on root of the inoculated tomato plants in in vitro experiments highlighted the ability of strains $A z O-$ tobacter chroococcum 67B and Azotobacter chroococcum 76A to colonize plant roots (Figure 5E, 5G). These results were confirmed by $\mathrm{Al}$ quantification in root plants observed by SEM (Figure 6A), which demonstrated that the $\mathrm{Al}$ percentage in the root zone colonized by $A$. chroococcum $76 \mathrm{~A}$ was higher than the one recovered in the non-colonized root zone (Figure 6B). 

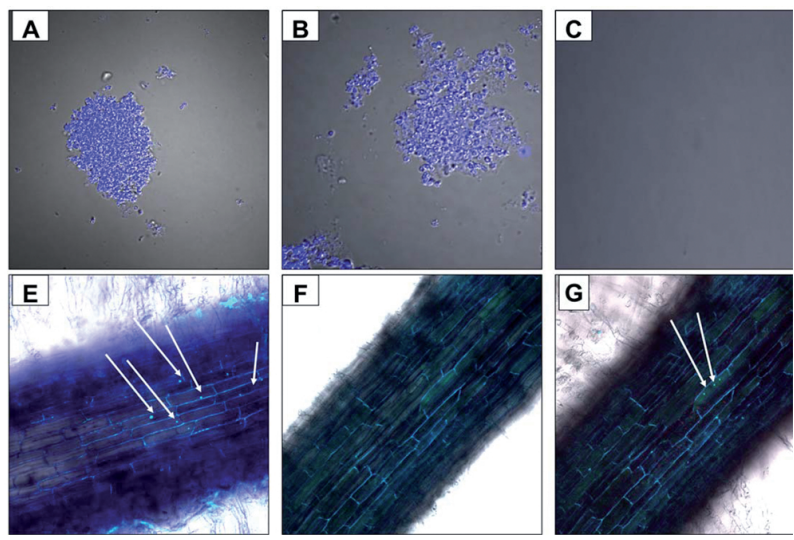

Figure 5. Confocal images of siderophore complex with aluminum (Al). A) Azotobacter chroococcum 67B in liquid medium with Al; B) Azotobacter chroococcum 76A in liquid medium with Al; C) non-inoculated control media with Al; D) Azotobacter chroococcum 76A strains in liquid growth medium without Al; E) Azotobacter chroococcum 76A strains on root epidermis in medium with Al; F) Root of non-inoculated plants in medium with Al, G) Azotobacter chroococcum 67B strains on root epidermis in medium with Al.

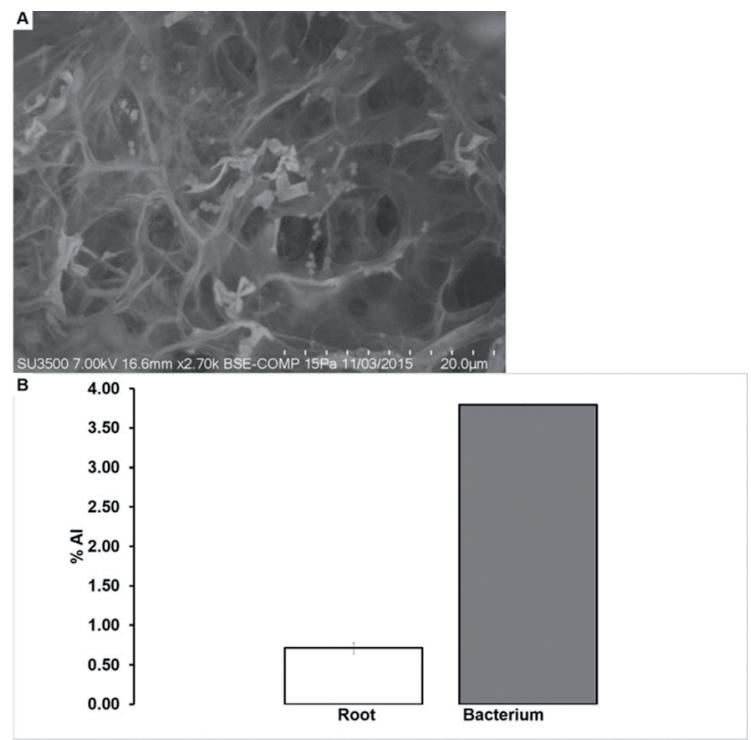

Figure 6. SEM image of strain Azotobacter chroococcum 76A colonizing tomato root (A) and Al percentage in non-colonized and colonized roots (B). 


\section{Discussion}

In recent years, the increasing demand for strategies and approaches improving the sustainability of agricultural systems has stimulated interest on the use of bioeffectors as alternative and/or complementary function to the use of chemical fertilizers. Plant growth-promoting bacteria (PGPB) fall in the category of bioeffectors, which exhibit several advantages for agricultural applications, including plant growth stimulation. They reduce plant susceptibility to soil-borne plant pathogens (Ventorino et al., 2016) as well as providescrossprotection against multiple stressors (Dimkpa et al., 2009; Ventorino et al., 2014). In this context, exploring plant growth promotion activities of bacterial strains isolated from different environments may provide important information to broaden their range of applications. Among the 106 bacterial strains evaluated in this study, two Azotobacter chroococcum strains were selected because of their high potential plant growth promotion properties and tolerance to drought and salt stress. These properties were considered as essential to assess the potential bioeffector function of these strains on tomato plants cultivated under drought or saline stress. Bacteria belonging to the genus Azotobacter have been largely used in agricultural applications as bio-fertilizers since they are able to fix atmospheric nitrogen $\left(\mathrm{N}_{2}\right)$ and increase nitrogen content in the soil under specific environmental conditions (Orr et al., 2011). We have previously reported the high $\mathrm{N}_{2}$-fixing activity of strain A. chroococcum 67B, which was able to increase about $27 \%$ the total nitrogen content in a mature compost obtained from agro-industrial wastes (Pepe et al., 2013a). Moreover, this strain as well as A. chroococcum 76A produced siderophores, had high ACC deaminase activity, synthetized IAA, showed Al tolerance, demonstrating to be a rhizocompetent strain and exerted antimicrobial activity against soil-borne plant pathogen related to tomato.
Rhizobacteria able to produce ACC deaminase can promote plant growth as well as protect plant against abiotic (drought, salt, flooding, inorganic and organic contaminants) and biotic stress (bacterial and fungal pathogens) (Glick, 2014). Penrose and Glick (2003) reported that levels of ACCd activity at $>20$ $\mathrm{nM} \alpha$-ketobutyrate mg protein $^{-1}$ were sufficient to promote host plant growth. Moreover, the transcription of ACC synthase that catalyzes the formation of ACC in plant could be induced by IAA (Glick, 2014). Production of IAA was reported in a wide variety of soil microorganisms contributing to plant-microbe interaction (Da Mota et al., 2008). This hormone is an important growth enhancer since it is the most efficient among auxins with a significant effect on plant root system development (Sharma et al., 2015). Recently, Barra et al. (2016) confirmed the importance of rhizocompetent stress tolerant bacterial strains with variable activity of the ACCd and production of the IAA for the alleviation of salt stress in plants.

The production of iron chelating siderophores is another important function of strains $A$. chroococcum 67B and A. chroococcum 76A with a dual effect of promoting plant growth by increasing nutrient availability to the plant and at the same time reducing iron availability for soil-borne plant pathogens (Chauhan et al., 2012). These properties have been documented in some Azotobacter species for which a remarkable antagonistic activity towards a wide range of phytopathogens was reported (Kravchenko et al., 2002). Moreover, our study highlighted the antimicrobial activity of $A$. chroococcum 76A against Sclerotinia minor for the first time. Specific antifungal activity of some $A$. chroococcum strains was observed against other pathogens as Rhizoctonia solani (Chauhan et al., 2012).

Strains A. chroococcum 67B and A. chroococcum $76 \mathrm{~A}$ showed also high tolerance to salt stress under controlled conditions since they exhibited an O.D.600 of $0.8-1$ at $5 \mathrm{~g} \mathrm{NaCl}^{-1}$ in liquid growth medium and 
remained viable for 56 days (approximately $7.5 \mathrm{Log}$ $\mathrm{CFU} \mathrm{\textrm {g } ^ { - 1 }}$ ) in quartz sand irrigated with saline solution and in presence of tomato plants. Similar results were found by Rojas-Tapias et al. (2012) who reported that salt did not exert negative effects on microbial growth of two selected strains of $A$. chroococcum, which reached an O.D. ${ }_{600}$ of about 0.2 at $5.85 \mathrm{~g} \mathrm{NaCl} \mathrm{1}^{-1}$. In addition, no difference recovered in CAT enzyme production by $A$. chroococcum $67 \mathrm{~B}$ and $A$. chroococcum $76 \mathrm{~A}$ in liquid media with high $\mathrm{NaCl}$ concentrations showed that salt stress did not exert any negative effect on metabolism of these strains. In fact, this antioxidant enzyme is involved in the mitigation of oxidative stress and safeguard cells against ROS damage, which determines membrane lipid component peroxidation (Kasim et al., 2013). Moreover, increase in proline production at the highest $\mathrm{NaCl}$ concentrations (7.5\% and $10 \%$ ) by A. chroococcum 76A highlighted the tolerance to osmotic stress of this strain. In particular, proline augmentation could induce the adjustment of cell osmotic potential, and cell adaptation under osmotic stress conditions (Marulanda et al., 2009).

A. chroococcum 67B and A. chroococcum 76A were also able to tolerate medium dehydration (drought stress) and improve the response of tomato seedlings to abrupt water loss. The ability of Azotobacter spp. and Pseudomonas spp. treatments to improve crop performance of fenugreek (Trigonella foenumgraecum L.) plants after deficit irrigation and drought stress was recently reported (Dadrasan et al., 2015). Microorganisms have developed different adaptation mechanisms to survive under stress conditions. Some bacteria, such as Azotobacter spp., are able to tolerate abiotic stress by producing a large quantity of exopolysaccharides (EPS) (Rehm, 2009). The EPS enhance water retention preserving microorganisms from water or salt stresses (Sandhya et al., 2009). In addition, EPS produced by microorganisms in the root zone of inoculated plants could have a key role in alleviating deleterious effects of abiotic stresses. Sandhya et al. (2009) noted an increase of resistance to water stress in sunflower plants treated with EPSproducing bacteria, probably due to their ability to improve soil structure in the rhizosphere. Moreover, EPS-producing bacteria could ameliorate negative effect of salt on plants by immobilazing $\mathrm{Na}^{+}$cations and reducing the actual toxicity of salinized soils/waters (Grover et al., 2011). Maize inoculated with selected strains of A. chroococcum showed plant growth and biomass increased only under saline stress condition (Rojas-Tapias et al., 2012). Currently we are testing this possibility with tomato plants using the stress tolerant strains selected in our laboratory.

Azotobacter chroococcum 67B and Azotobacter chroococcum 76A were also able to form complexes with $\mathrm{Al}^{+3}$ in in vitro assay with tomato plant under sterile conditions into liquid growth medium, demonstrating ability to colonize plant roots. The ability of siderophores to bind Al was reported by Del Olmo et al. (2003). The method used in this work could be a hopeful new technique of tagging in growth media, that not only allowed us to understand the behavior of Azotobacter chroococcum strains in the tomato rhizosphere in vitro, but also give information about their tolerance to $\mathrm{Al}^{3+}$, revealing a possible strategy in $\mathrm{Al}$ chelation. However, further experiments are necessary to understand the interaction of $\mathrm{Al}^{3+}$-siderophore complex in root colonization.

\section{Conclusions}

The selected $\mathrm{N}_{2}$-fixing and rhizocompetent strains Azotobacter chroococcum 67B and Azotobacter chroococcum 76A showed multiple plant growth promotion activities because they were able to synthetize siderophores and IAA showing also ACC deaminase activity and exerting antimicrobial activity against 
Sclerotinia minor CBS 112.17. To our knowledge, this is the first work reporting antifungal activity against Sclerotinia minor in A. chroococcum. Interestingly, the two bacterial strains of Azotobacter exhibited high tolerance to salt and drought stresses and could alleviate the negative effects exerted by abiotic stress in tomato plants. Overall results showed that the two strains selected in this study could be interesting candidates to be employed as bio-effector in sustainable agricultural systems also under stressful conditions leading to great economic and environmental benefits.

\section{Acknowledgments}

This work was supported by Research project BIOFECTOR-“"Resource Preservation by Application of BIOefFECTORs in European Crop Production"- Grant Agmt. No. 312117, by Fondecyt Project n. 1141247, and Fondecyt Proyect n.11154504. Moreover the authors would like to thanks Nucleus of Scientific and Technological Development in Bioresources of Universidad de La Frontera- TemucoChile for technical support.

\section{References}

Anastasio, M., Pepe, O., Cirillo, T., Palomba, S., Blaiotta, G., Villani, F. 2010. Selection and use of phytate-degrading LAB to improve cereal-based products by mineral solubilization during dough fermentation. J. Food Sci. 75, 28-35.

Armada, E., López-Castillo, O., Roldán, A., Azcón, R. 2016. Potential of mycorrhizal inocula to improve growth, nutrition and enzymatic activities in Retama sphaerocarpa compared with chemical fertilization under drought conditions. J. Soil Sci. Plant Nutr. 16, 380-399.

Barra, P.J., Inostroza, N.G., Acuña, J.J., Mora, M.L., Crowley, D.E., Jorquera, M.A. 2016. Formula- tion of bacterial consortia from avocado (Persea americana Mill.) and their effect on growth, biomass and superoxide dismutase activity of wheat seedlings under salt stress. Appl. Soil Ecol. 102, 80-91.

Bates, L.S., Waldren, R.P., Teare, I.D. 1973. Rapid determination of free proline for water-stress studies. Plant Soil 39, 205-207.

Bojadzhieva, I., Emanuilova, E. 2005. Characteristics of bacterial strain, superoxide dismutase producer, isolated from bulgarian thermal spring. J. Cult. Collect 4, 61-67.

Chauhan, S., Wadhwa, K., Vasudeva, M., Narula, N. 2012. Potential of Azotobacter spp. as biocontrol agents against Rhizoctonia solani and Fusarium oxysporum in cotton (Gossypium hirsutum), guar (Cyamopsis tetragonoloba) and tomato (Lycopersicum esculentum). Arch. Agron. Soil Sci. 58, 1365-1385.

Da Mota, F.F., Gomes, E.A., Seldin, L. 2008. Auxin production and detection of the gene coding for the Auxin Efflux Carrier (AEC) protein in Paenibacillus polymyxa. J. Microbiol. 46, 257-264.

Dadrasan, M., Chaichi, M.R., Pourbabaee, A.A., Yazdani, D., Keshavarz-Afshar, R. 2015. Deficit irrigation and biological fertilizer influence on yield and trigonelline production of fenugreek. Ind. Crop Prod. 77, 156-162.

Del Olmo, A., Caramelo, C., SanJose, C. 2003. Fluorescent complex of pyoverdin with aluminum. J. Inorg. Biochem. 97, 384-387.

Dimkpa, C., Weinand, T., Asch, F. 2009. Plant-rhizobacteria interactions alleviate abiotic stress conditions. Plant Cell Environ. 32, 1682-1694.

Durán, P., Acuña, J.J., Gianfreda, L., Azcon, V., Funes-Collado, V., Mora, M.L. 2015. Endophytic selenobacteria as new inocula for selenium biofortification. Appl. Soil Ecol. 96, 319-326. 
Durán, P., Acuña, J.J., Armada, E., López-Castillo, O.M., Cornejo, P., Mora, M.L., Azcón, R. 2016. Inoculation with selenobacteria and arbuscular mycorrhizal fungi to enhance selenium content in lettuce plants and improve tolerance against drought stress. J. Soil Sci. Plant Nutr. 16, 201-225.

Flowers, T.J. 2004. Improving crop salt tolerance. J. Exp. Bot. 55, 307-319. Gauri, S.S., Mandal, S.M., Pati, B.R. 2012. Impact of Azotobacter exopolysaccharides on sustainable agriculture. Appl. Microbiol. Biotechnol. 95, 331-8.

Glick, B.R. 2014. Bacteria with ACC deaminase can promote plant growth and help to feed the world. Microbiol. Res. 169, 30-39.

Grover, M., Ali, S.Z., Sandhya, V., Rasul, A., Venkateswarlu, B. 2011. Role of microorganisms in adaptation of agriculture crops to abiotic stresses. World J. Microbiol. Biotechnol. 27, 1231-1240.

Hammami, I., Ben Hsouna, A., Hamdi, N., Gdoura, R., Triki, M.A. 2013. Isolation and characterization of rhizosphere bacteria for the biocontrol of the damping-off disease of tomatoes in Tunisia. C. R. Biol. 336, 557-64.

Islam, M.R., Sultana, T., Joe, M.M., Yim, W., Cho, J.C., Sa, T. 2013. Nitrogen-fixing bacteria with multiple plant growth-promoting activities enhance growth of tomato and red pepper. J. Basic Microbiol. 53, 1004-1015.

Kasim, W.A., Osman, M.E., Omar, M.N., Abd ElDaim, I.A., Bejai, S., Meijer, J. 2013. Control of drough stress in wheat using plant growthpromoting bacteria. J. Plant Growth Regul. 32, 122-130.

Kravchenko, L.V., Makarova, N.M., Azarova, T.S., Provorov, N.A., Tikhonovich, I.A. 2002. Isolation and phenotypic characterization of plant growthpromoting rhizobacteria with high antiphytopathogenic activity and root-colonizing Ability. Microbiology 71, 444-448.
Lin, X., Xu X., Yang, C., Zhao, Y., Feng, Z., Dong, Y. 2009. Activities of antioxidant enzymes in three bacteria exposed to bensulfuron-methyl. Ecotoxicol. Environ. Saf. 72, 1899-1904.

Maggio A., Raimondi G., Martino A., De Pascale S. 2007. Salt stress response in tomato beyond the salinity tolerance threshold. Environ. Exp. Bot. 59, 276-282.

Marulanda, A., Barea J.M., Azcón, R. 2009. Stimulation of plant growth and drought tolerance by native microorganisms (AM Fungi and bacteria) from dry environments: Mechanisms related to bacterial effectiveness. J. Plant Growth Regul. 28, 115-124.

Penrose, D.M., Glick, B.R. 2003. Methods for isolating and characterizing ACC deaminase-containing plant growth-promoting rhizobacteria. Physiol. Plant 118, 10-15.

Pepe, O., Ventorino, V., Blaiotta, G. 2013a. Dynamic of functional microbial groups during mesophilic composting of agro-industrial wastes and free-living $\left(\mathrm{N}_{2}\right)$-fixing bacteria application. Waste Manage. 33, 1616-1625.

Pepe, O., Ventorino, V., Cavella, S., Fagnano, M., Brugno, R. 2013b. Prebiotic content of bread prepared with flour from immature wheat grain and selected dextran-producing lactic acid bacteria. Appl. Environ. Microbiol. 79, 3779-3785.

Priefer, U. 2001. Characterisation of Phaseolus symbionts isolated from Mediterranean soils and analysis of genetic factors related to $\mathrm{pH}$ tolerance. $\mathrm{J}$. Biotechnol. 91, 223-236.

Rehm, B.H.A. 2009. Microbial production of biopolymers and polymer precursors: applications and perspectives. Caister Academic Press, Haverhill, UK.

Ribeiro, C.M., Cardoso, E.J.B.N. 2012. Isolation, selection and characterization of root-associated growth promoting bacteria in Brazil Pine (Araucaria angustifolia). Microbiol. Res. 167, 69-78. 
Rojas-Tapias, D., Moreno-Galván, A., Pardo-Díaz, S., Obando, M., Rivera, D., Bonilla, R. 2012. Effect of inoculation with plant growth-promoting bacteria (PGPB) on amelioration of saline stress in maize (Zea mays). Appl. Soil Ecol. 61, 264-272.

Rozema, J., Flowers, T. 2008. Ecology. Crops for a salinized world. Science. 322,1478-1480.

Ruzzi, M., Aroca, R. 2015. Plant growth-promoting rhizobacteria act as biostimulants in horticulture. Sci. Hortic. 196, 124-134.

Sandhya, V.Z.A.S., Grover, M., Reddy, G., Venkateswarlu, B. 2009. Alleviation of drought stress effects in sunflower seedlings by the exopolysaccharides producing Pseudomonas putida strain GAP-p45. Biol. Fertil. Soils 46, 17-26.

Sharma, V., Kamal B., Srivastava, N., Negi, Y., Dobriyal, A.K., Jadon, V.S. 2015. Enhancement of in vitro growth of Swertia chirayita Roxb. Ex Fleming co-cultured with plant growth promoting rhizobacteria. Plant Cell Tiss. Organ. Cult. 121, 215-225.

Silva-Stenico, M.E., Pacheco, F.T.H., Rodrigues, J.L.M., Carrilho, E., Siu, M.T. 2005. Growth and siderophore production of Xylella fastidiosa under iron-limited conditions. Microbiol. Res. 160, 429-436.

Ventorino, V., Caputo, R., De Pascale, S., Fagnano, M., Pepe, O., Moschetti, G. 2012. Response to salinity stress of Rhizobium leguminosarum bv. viciae strains in the presence of different legume host plants. Ann. Microbiol. 62, 811-823.
Ventorino, V., Sannino, F., Piccolo, A., Cafaro, V., Carotenuto, R., Pepe, O. 2014. Methylobacterium populi VP2: Plant growth-promoting bacterium isolated from a highly polluted environment for polycyclic aromatic hydrocarbon (PAH) biodegradation. Sci. World J. Article ID 931793. Doi: 10.1155/2014/931793

Ventorino, V., Aliberti, A., Faraco, V., Robertiello, A., Giacobbe, S., Ercolini, D., Amore, A., Fagnano, M., Pepe, O. 2015. Exploring the microbiota dynamics related to vegetable biomasses degradation and study of lignocellulose-degrading bacteria for industrial biotechnological application. Sci. Rep. 5, 8161. doi:10.1038/srep08161.

Ventorino, V., Parillo, R., Testa, A., Viscardi, S., Espresso, F., Pepe, O. 2016. Chestnut green waste composting for sustainable forest management: Microbiota dynamics and impact on plant disease control. J. Environ. Manage. 166, 168-177.

Whiteley, C.G., Lee, D.J. 2006. Enzyme technology and biological remediation. Enzyme Microb. Tech. 38, 291-316.

Yang, J., Kloepper, J.W., Ryu, C.M. 2009. Rhizosphere bacteria help plants tolerate abiotic stress. Trends Plant Sci. 14, 1-4. 